\title{
Analisis Pengaruh Tingkat Hunian Pasien (BOR), Anggaran Biaya Operasional Dan Rasio Aktivitas Terhadap Kinerja Keuangan Berdasarkan Kemampuan Pendapatan PNBP Menutupi Biaya Operasional Badan Layanan Umum(BLU) Rumah Sakit Provinsi DKI Jakarta.
}

\author{
Istiqomah Dwi Putri \\ Achmad Fauzi \\ Email: istiqomahdwiputri@gmail.com \\ Fakultas Ekonomi Universitas Negeri Jakarta
}

\begin{abstract}
Abstrak
The purpose of this research is to know the influence of activity, operational cost budgeting, and bed occupancy rate on financial performance based on ability of (PNBP) revenue to cover operating cost public service agency hospital. This study aims to determine the effect of patient occupancy rate (BOR), operational budget and activities of financial performance is based on the ability of non-tax revenue to cover operating costs hospital public service agencies in the province of Jakarta period 2011-2015.

Descriptive analysis showed that: (a) the value of BOR at Hospital studied quite well with a range of over $60 \%,(b)$ the absorption of operational budget is considered quite efficient because it has a small difference from the budget, $(c)$ the ratio of activity with time measurement average receivables collectible on average figures,

The results of this study indicate that patient occupancy rate (BOR), and Budget operasionalof positive and significant impact on the financial performance Hospital General Services Agency activity while variable does not affect the financial performance of the Hospital
\end{abstract}

Key words: Finacial Performance, BOR, Budgeting Operation,Activity Ratio.

\section{PENDAHULUAN}

\section{A. Latar Belakang Masalah}

Pelayanan publik saat ini sangat erat kaitannya dengan reformasi administrasi publik yang telah terjadi pada dunia sejak hampir dua dekade belakangan, tema New Public Management (NPM) / Reinventing Government yang di dasarkan atas pengalaman negara-negara Eropa, Amerika Serikat, Australia, dan Selandia Baru secara berangsur-angsur diadopsi ke dalam manajemen pemerintahan terkait pelayanan publik di berbagai negara, termasuk Indonesia.

Transformasi manajemen pemerintahan dalam New Public Management (NPM) mulai dari penataan kelembagaan / Institutional Arrangement, reformasi kepegawaian / Civil Servant Reform, dan reformasi pengelolaan keuangan Negara / New Management Reform (Mahmudi, 2003)

Pemerintah sendiri telah melakukan reformasi keuangan negara yang mulai bergulir sejak akhir tahun 2003, dengan dikeluarkannya tiga paket peraturan

Jurnal IImiah Wahana Akuntansi

Volume 12 No.01, Tahun 2017 
keuangan negara yang baru, yaitu UU No. 17 tahun 2003 tentang Keuangan Negara, UU No. 1 Tahun 2004 tentang Perbendaharaan Negara, dan UU No. 15 Tahun 2005 tentang Pemeriksaan Keuangan Negara. Dengan ketiga paket peraturan keuangan negara tersebut telah mengubah mindset atau pola pikir yang lebih efisien, profesionalitas, akuntabel, dan transparan dengan melakukan perubahan dari penganggaran tradisional menjadi penganggaran berbasis kinerja yang membuka koridor bagi penerapan basis kinerja di lingkungan pemerintah (Hag, 2009). Berdasarkan Undang-undang tersebut, instansi pemerintah yang tugas pokok dan fungsinya memberikan pelayanan kepada masyarakat dapat menerapkan pola pengelolaan keuangan yang fleksibel, berupa keleluasaan untuk menerapkan praktek-praktek bisnis yang sehat dalam rangka memaksimalkan pelayanan kepada masyarakat dengan tetap menonjolkan produktivitas, efisiensi, dan efektivitas melalui Badan Layanan Umum.

Badan Layanan Umum (disingkat BLU) adalah instansi di lingkungan Pemerintah yang dibentuk untuk memberikan pelayanan kepada masyarakat berupa penyediaan barang dan/atau jasa yang dijual tanpa mengutamakan mencari keuntungan dan dalam melakukan kegiatannya didasarkan pada prinsip efisiensi dan produktifitas.BLU terdapat di lingkungan pemerintah pusat dan pemerintah daerah.BLU di daerah disebut Badan Layanan Umum Daerah (disingkat BLUD).Saat ini BLU di Indonesia berjumlah 156 unit satuan kerja per Oktober 2016.

Rumah sakit merupakan institusi yang padat modal, baik dari segi teknologi maupun tenaga kerja sehingga pengelolaan rumah sakit tidak bisa sebagai unit sosial saja, tetapi juga dari segi ekonomi harus diperhitungkan.Dari paradigma tersebut membuat rumah sakit harus mempertanggungjawabkan kinerja secara menyeluruh, baik kinerja dari pelayanan rumah sakit tersebut dari segi keuangan maupun non keuangan dengan memperhatikan standar mutu pelayanan yang senantiasa terus menerus perlu ditingkatkan.

Biaya kesehatan yang cenderung terus meningkat, menjadikan rumah sakit terutama rumah sakit milik pemerintah dituntut untuk secara mandiri mengatasi masalah tersebut.Hal ini menjadi permasalahan tersendiri bagi rumah sakit pemerintah karena segmen pelanggan mereka kebanyakan adalah masyarakat kalangan menengah ke bawah.Untuk meningkatkan pelayanan kepada masyarakat, rumah sakit diharapkan untuk dapat meningkatkan kualitas pelayanan, efisiensi dan efektifitas dalam pemberian pelayanan. Rumah sakit sebagai salah satu institusi pelayanan publik memegang peranan penting bagi peningkatan derajat kesehatan masyarakat.Rumah sakit dituntut untuk dapat melayani masyarakat, dapat berkembang dan mandiri serta harus mampu bersaing dan memberikan pelayanan yang bermutu dan terjangkau bagi masyarakat.

Sebagai lembaga yang padat modal, padat karya, dan padat ilmu serta teknologi, rumah sakit ini memerlukan profesionalisme yang handal dalam pengelolaan bisnis modern. Melalui Pola Pengelolaan Keuangan Badan Layanan Umum (PPK-BLU), BLU pada sektor kesehatan mampu meningkatkan kinerja pelayanannya 
kepada masyarakat dalam rangka memajukan kesejahteraan umum dan mencerdaskaan kehidupan bangsa, dengan memberikan fleksibilitas dalam pengelolaan keuangan berdasarkan prinsip ekonomi dan produktivitas, dan penerapan praktek bisnis yang sehat.

Penilaian kinerja terhadap lembaga atau organisasi tidak hanya berlaku pada lembaga atau organisasi yang berorientasi profit saja, melainkan juga perlu dilakukan pada lembaga atau organisasi non komersial.

Kinerja keuangan merupakan faktor penting untuk menilai keseluruhan kinerja organisasi atau dapat diartikan sebagai kondisi organisasi.Untuk menganalisis kinerja keuangan suatu organisasi diperlukan ukuran-ukuran tertentu.Dengan rasio keuangan, dapat diketahui bagaimana kinerja keuangan suatu organisasi.

Salah satu agenda reformasi keuangan negara adalah adanya pergeseran dari pengganggaran tradisional menjadi pengganggaran berbasis kinerja. Dengan basis kinerja ini, arah penggunaan dana pemerintah tidak lagi berorientasi pada input, tetapi pada output. Perubahan ini penting dalam rangka proses pembelajaran untuk menggunakan sumber daya pemerintah yang makin terbatas, tetapi tetap dapat memenuhi kebutuhan dana yang makin tinggi.

Penelitian kinerja keuangan pada rumah sakit pemerintah yang telah menjadi badan layanan umum dirasa sangat perlu untuk mengatahui bagiamana kinerja real yang terjadi pada saat pengimplementasian pengelolaan keuangan yang disebut fleksibel sehingga menghasilkan kinerja keuangan yang baik terutama di daerah DKI Jakarta sebagai ibukota
Negara, yang menjadi ujung tombak perekonomian Indonesia yang diharapkan bisa memberikan gambaran akan kinerja keuangan, pelayanan, penganggaran dan aktivitas pada badan layanan umum itu sendiri.

Pelayanan publik yang tepat sasaran, penggunaan anggaran yang efektif serta pengelolaan aktivitas merupakan hal penting untuk kesuksesan Negara dalam upaya meningkatkan kualitas kesejahteraan masyarakat guna mempercepat pertumbuhan ekonomi.

Berdasarkan uraian latar belakang di atas maka peneliti tertarik untuk meneliti dengan judul "Analisis Pengaruh Tingkat Hunian Pasien (BOR), Anggaran Biaya Operasional Dan Rasio Aktivitas Terhadap Kinerja Keuangan Berdasarkan Kemampuan Pendapatan PNBP Menutupi Biaya Operasional Badan Layanan Umum Rumah Sakit Di Provinsi Dki Jakarta".

\section{B. Identifikasi Masalah}

Dari latar belakang masalah di atas, penulis mengidentifikasikan masalah pada penelitian ini, yaitu:

1. Pergeseran paradigma administrasi tradisional yang cenderung mengutamakan sistem dan prosedur, birokratis yang tidak efisien, pemberian layanan yang lambat serta tidak efektif.

2. Kualitas penyeleggaran pelayanan public saat ini yang masih rendah, yang mana efektifitas penyelenggaraan suatu pemerintah sangat ditentukan oleh baik buruknya penyelenggaraan pelayanan public.

3. Persepsi masyarakat akan rendahnya sistem pelayanan rumah sakit pemerintah, menyebabkan 
tuntutan pembenahan sistem efektifitas pelayanannya.

4. Efektifitas penganggaran pada pelayanan public yang memerlukan tinjauan berkala guna keselarasan .

\section{Pembatasan Masalah}

Dari berbagai masalah yang diidentifikasikan di atas, penelitian ini dibatasi pada masalah pada "tingkat hunian kamar pasien, anggaran biaya operasional, dan pengelolaan aktivitas terhadap kinerja keuangan berdasarkan kemampuan pendapatan menutupi biaya operasional badan layanan umum rumah sakit di provinsi DKI Jakarta" dengan periode pengamatan penelitian selama 5 tahun (2011-2015)."

\section{Perumusan Masalah}

Berdasarkan latar belakang yang ada, maka rumusan masalah dalam penelitian ini yaitu:

a. Apakah tingkat hunian pasien (BOR),berpengaruh terhadap kinerja keuangan BLU Rumah Sakit di Provinsi DKI Jakarta?

b. Apakah anggaran biaya operasional berpengaruh terhadap kinerja keuangan BLU Rumah Sakit di Provinsi DKI Jakarta?

c. Apakah rasio Aktivitas berpengaruh terhadap kinerja keuangan Badan Layanan Umum Rumah Sakit di Provinsi DKI Jakarta?

\section{E. Kegunaan Penelitian}

Adapun kegunaan dari penelitian ini adalah sebagai berikut:

a. Kegunaan Teoritis

$\begin{array}{lr}\text { Secara teoritis, } & \text { penelitian } \\ \text { inidiharapkan menambah } & \text { mawasan dan pemahaman } \\ \text { waw } & \text { tingkat } \\ \text { mengenaipengaruh } & \text { hunian, anggaran biaya }\end{array}$

Jurnal IImiah Wahana Akuntansi operasional, dan rasio aktivitas terhadap kinerja keuangan badan layanan umum rumah sakit sehingga dapat digunakan sebagai referensi untuk peneliti lain atau bagi kalangan akademis untuk penelitian selanjutnya.

b. Kegunaan Praktis

Penelitian ini diharapkan dapat memberikan masukan dan evaluasi khusus kepada sektor public khususnya pemerintah, badan layanan umum itu sendiri, serta masyarakat luas yang memberikan gambaran secara terang terkait pembahasan penelitian ini dan bisa menjadi refrensi pemecahan masalah yang dikaji secara akademis.

\section{KAJIAN TEORETIK}

\section{A. Deskripsi Konseptual}

Principal-Agent dalam BLU

Pada proses reformasi birokrasi, ada pendekatan yang dapat digunakan ketika suatu pelayanan disampaikan kepada publik (masyarakat). Model pendekatan tersebut disebut pendekatan principal-agent (Batley, 2004).

Menurut Lane, Stiglitz, dan Walsh, pada teori principal-agent, agent berusaha memenuhi keinginan dari principal, karena principal pada dasarnya adalah merupakan representasi kepentingan publik. Dengan kata lain, principal disini dapat juga berperan sebagai "controller" agent. Hal ini dikarenakan dalam kondisi politik yang demokratis, pemegang kekuasaan tertinggi adalah warga masyarakat (citizen) atau konsumen dari pelayanan publik (Batley, 2004). 
Pendekatan principal-agent ini menjadi dasar untukmenempatkan birokrat sebagai pelayan masyarakat yang sebenarnya.Penerapan pendekatan ini diharapkan mampu menyadarkan birokrat sebagai agent yang bertanggung jawab kepada masyarakat (principal) dan bukan sebaliknya.

Menurut UU No 1 tahun 2004 tentang Perbendahaan Negara, konsep principal-agent yang berlaku di BLU disebutkan bahwa yang menjadi principal adalah pemerintah melalui menteri atau pimpinan lembaga dan yang menjadi agen adalah satuan kerja instansi pemerintah (satker). Menteri/pimpinan lembaga sebagai policy maker dan satuan kerja sebagai pelaksananya (BLU bertanggungjawab untuk menyajikan layanan yang diminta kepada menteri sebagai principal).

\section{Pengertian Kinerja dan Pengukuran Kinerja Keuangan(Y)} Kinerja berasal dari kata performance, kinerja dinyatakan sebagai prestasi yang dicapai oleh perusahaan dalam suatu periode tertentu yang mencerminkan tingkat kesehatan dari perusahaan tersebut. Pengukuran kinerja adalah penentuan secara periodik tampilan perusahaan yang berupa kegiatan operasional, struktur organisasi, dan karyawan yang berdasarkan sasaran, standar dan kriteria yang telah ditetapkan sebelumnya (Mulyadi, 1997:419).

Pengukuran kinerja keuangan mempunyai arti yang penting bagi pengambilan keputusan baik bagi pihak intern maupunekstern perusahaan. Laporan keuangan merupakan alat yang dijadikan acuan penilaian untuk meramalkan kondisi keuangan, operasi, dan hasil usaha perusahaan.

\section{Sistem Penilaian Kinerja Rumah Sakit}

Sistem penilaian kinerja melalui indikator merupakan salah satu alat yang dapat digunakan untuk menilai suatu proses kegiatan BLU Rumah Sakit secara terus menerus. Sebagai rumah sakit milik Negara, BLU rumah sakit harus mampu memberikan informasi yang menggambarkan kemajuan rumah sakit pada suatu periode tertentu. Indikator kinerja rumah sakit BLU mengacu pada Keputusan Menteri Negara Pendayagunaan BUMN No.KEP215/ M.BUMN/1999 tanggal 27 September 1999 dan disempurnakan melalui Keputusan Menteri BUMN No. 100/MBU/2002 tanggal 4 Juni 2002 tentang penilaian tingkat kesehatan Badan Usaha Milik Negara, yang kemudian disesuaikan dengan jenis dan sifat kegiatan rumah sakit melalui Kepmenkes

NO. 550/Menkes/SK/VII/2009 tentang Pedoman Penyusunan Rencana Bisnis dan Anggaran (RBA) Badan Layanan Umum Rumah Sakit. Jenis indikator yang dinilai untuk BLU rumah sakit sesuai Kementrian Keuangan Republik Indonesia Peraturan Direktur Jendral Perbendaharaan Nomor PER/34/PB/2014 meliputi tiga aspek, yaitu: Indikator Kinerja Keuangan, Indikator Kinerja Operasional, Indikator kinerja mutu pelayanan dan manfaat bagi masyarakat. Dengan Indikator Kinerja Keuangan berdasarkan rasio keuangan dengan cara menghubungkan elemen-elemen laporan keuangan sebagai berikut :

1. Rasio Kas (Cash Ratio)

2. Rasio Lancar (Current Ratio) 
3. Periode Penagihan Piutang (Collection Period)

4. Perputaran Aset Tetap (Fixed Asset Turnover)

5. Imbalan Atas Aset Tetap (Return on Fixed Asset) ROFA

6. Imbalan Ekuitas (Return on Equity) ROE

7. Perputaran Persediaan (Inventory Turnover)

8. Rasio Pendapatan PNBP terhadap Biaya Operasional

9. Rasio Subsidi Biaya Pasien

\section{Tingkat Hunian Pasien atau Bed Occupancy Rate (BOR) (X1)}

Sesuai dengan UUD 1945, pembangunan kesehatan merupakan upaya untuk memenuhi salah satu hak dasar rakyat, yaitu hak untuk memperoleh pelayanan kesehatan. Misalnya, pelayanan kesehatan di rumah sakit . Rumah sakit sebagai salah satu fasilitas pelayanan kesehatan memiliki peran yang sangat strategis dalam upaya mempercepat derajat kesehatan masyarakat Indonesia. Pembangunan kesehatan harus dipandang sebagai suatu investasi untuk peningkatan kualitas sumber daya manusia dan mendukung pembangunan ekonomi, serta memiliki peran penting dalam upaya penanggulangan kemiskinan. Pemerintah telah bersungguh-sungguh dan terus-menerus berupaya untuk meningkatkan mutu pelayanan baik yang bersifat promotif, preventif, kuratif dan rehabilitasi.

Dalam rangka meningkatkan derajat kesehatan masyarakat banyak hal yang perlu diperhatikan. Salah satu diantaranya yang dianggap mempunyai peranan yang cukup penting adalah penyelenggaraan pelayanan kesehatan. Agar penyelenggaraan pelayanan kesehatan dapat mencapai tujuan yang diinginkan maka pelayanan harus memenuhi berbagai syarat diantaranya, tersedia dan berkesinambungan, dapat diterima dan wajar, mudah dicapai, mudah dijangkau, dan bermutu.

Pelayanan kesehatan yang bermutu merupakan salah satu tolak ukur kepuasan yang berefek terhadap keinginan pasien untuk kembali kepada institusi yang memberikan pelayanan kesehatan yang efektif. Untuk memenuhi kebutuhan dan keinginan pasien sehingga dapat memperoleh kepuasan yang ada pada akhirnya dapat meningkatkan kepercayaan pada rumah sakit melalui pelayanan prima. Melalui pelayanan prima, rumah sakit diharapkan akan menghasilkan keunggulan kompetitif dengan pelayanan bermutu, efisien, dan inovatif. Misal, bentuk pelayanan yang efektif antara pasien dan pemberi pelayanan disadari sering terjadi perbedaan persepsi. Pasien mengartikan pelayanan yang bermutu dan efektif jika pelayanannya nyaman, menyenangkan dan petugasnya ramah yang mana secara keseluruhan memberikan kesan kepuasan terhadap pasien. Sedangkan, provider mengartikan pelayanan yang bermutu dan efesien jika pelayanan sesuai dengan standar pemerintah. Adanya perbedaan persepsi tersebut sering menyebabkan keluhan terhadap pelayanan.

Menurut Departemen Kesehatan RI, BOR adalah prosentase pemakaiantempat tidur pada periode tertentu. Indikator ini memberikan gambarantinggi rendahnya tingkat pemanfaatan tempat tidur di rumah sakit. Nilaiparameter BOR yang ideal 
adalah antara 60-85\% (Depkes RI, 2005). Kondisi tersebut merupakan kondisi yang standar sebab jika nilai BOR ada dibawah kondisi tersebut maka menunjukkan rendahnya pemanfaatan tempat tidur, jika nilai BOR diatas berarti semua tempat tidur dipergunakan sepanjang tahun, hal ini secara medis kurang baik karena tidak adanya jedah waktu untuk membersihkan sehingga continuous improvement quality sulit dicapai. Sedangkan jika nilai diatas 100 merupakan kondisi yang sangat parah karena satu tempat tidur digunakan lebih dari satu pasien (extra bed).

Adapun rumus BOR adalah:

$\mathrm{BOR}=$

Jumlah hari perawatan rumah sakitx $100 \%$

(Jumlah tempat tidur $\mathrm{x}$ jumlah hari dalam satu periode)

\section{Anggaran Biaya Operasional (X2)}

Di dalam melaksanakan kegiatan usahanya, setiap satuan kerja selalu dihadapkan pada masa yang penuh dengan ketidakpastian, sehingga akan menimbulkan masalah pemilihan dari berbagai alternatif kebijakan yang akan ditempuhnya dalam melaksanakan kegiatan usahanya tersebut. Di samping itu, dalam pelaksanaan kebijakan yang telah diputuskan tersebut, perlu adanya suatu alat untuk mengkordinasikan semua kegiatan agar dapat berjalan secara resmi dan terkendali. Untuk keperluan tersebut banyak sarana manajemen yang dapat dipergunakan dan salah satunya dalam bentuk anggaran. Secara umum anggaran dapat didefinisikan :

Menurut Carter dan Usri (2004:13) mendefenisikan "Anggaran (Budget) adalah pernyataan terkuantifikasi dan tertulis dari rencana manajemen". Menurut Sukarno (2004:144) mendefenisikan "Anggaran adalah rencana yang terorganisasi dan menyeluruh dinyatakan dalam unit moneter untuk operasi

dan sumber daya suatu satuan kerja selam periode tertentu dimasa yang akan datang ".

Anggaran biaya operasional adalah anggaran atau taksiran semua biaya yang dikeluarkan dan pada hakekatnya dianggap habis dalam masa tahun buku.

Indikator efisiensi, adalah suatu indikator yang menggambarkan hubungan antara masukan sumber daya oleh suati unit organisasi (misalnya : staff, upah, biaya administratif) dan keluaran yang dihasilkan indikator tersebut memberikan informasi tentang konversi masukan menjadi keluaran (yaitu : efisiensi dari proses internal)Pengelolaan sumberdaya yang tepat diharapkan

Pengukuran Efesiensi Anggaran Biaya Operasional $=$

Realisasi (output)x $\quad 100 \%$ Anggaran(input)

\section{Rasio Aktivitas (X3)}

Menurut Fahmi (2013), rasio aktivitas adalah : Rasio yang menggambarkan sejauh mana suatu perusahaan mempergunakan sumber daya yang dimilikinya guna menunjang aktivitas perusahaan, dimana penggunaan aktivitas ini dilakukan secara sangat maksimal dengan maksud memperoleh hasil yang maksimal.

Dalam praktiknya rasio aktivitas yang digunakan perusahaan memiliki beberapa tujuan yang hendak dicapai. Raio aktivitas juga memberikan banyak manfaat bagi kepentingan 
perusahaan maupun bagi pihak luar perusahaan, untuk masa sekarang maupun yang akan datang. Menurut Kasmir (2012).

\section{B. Hasil Penelitian yang Relevan}

Beberapa peneliti telah melakukan penelitian terkait pengaruh Tingkat Hunian Pasien atau disebut Bed Occupancy Rate (BOR) terhadap kinerja keuangan seperti, Yusri Chaeroniza (2014) melakukan penelitian analisis BOR untuk menilaikinerja keuangan pada Rumah Sakit Bogor Medikal Center. Hasil penelitian yang diperoleh menyatakan bahwa kinerja pelayananmelalui pengukuran BOR memiliki pengaruh positif yang signifikan terhadap kinerja keuangan.Peningkatan nilai tingkat hunian (BOR) searah dengan peningkatan kinerja keuangan.

Dwi Putri, dkk (2014) , menguraikan dalam penelitiannya terkait variable bebas yang terakhir yaitu Rasio Aktivitas, penelitian menunjukan bahwa rasio aktivitas berpengaruh tidak signifikan terhadap kinerja keuangan perusahaan dengan judul pengaruh rasio likuiditas, rasio leverage dan rasio aktivitas terhadap kinerja keuangan Perusahaan (food and bavarege company BEI 20102012)terdapat pengaruh baik secara simultan maupun parsial antar variable yang diteliti danjugaRasio. Semakin tinggi rasio aktivitas maka akan semakin baik pula bagiperusahaan, hal ini berarti tingkat rasio aktivitasnya berjalan cepat pula.sehingga rasio aktivitas berpengaruh terhadap kinerja keuangan.

Berbeda dengan Artikel penelitian

R.M. Riadi (2014) tentang analisis pengaruh rasio aktivitas terhadapkinerja keuangan rentabilitas ekonomi pada perusahaan Plastics And Glass Products Yang Go Publik Di Bursa Efek Jakarta yang menyebutkan bahwa rasio aktivitas tidak mempengaruhiterhadap kinerja keuangan (rentabilitas ekonomi) pada perusahaan Plastik and Glass Products dan sejalan dengan penelitian selanjutnya tentang kinerja keuangan pada Rumah Sakit Jiwa Prof.HB.Saanin yang dilakukan oleh chairun amalia(2013), tentang Analisis pengaruh rasio Likuiditas, rasio Aktivitas, rasio profitabilitas, dan rasio Struktur Modal, bahwa rasio Likuiditas, rasio Aktivitas, rasio profitabilitas, dan rasio Struktur Modal tidak berpengaruh terhdap kinerja keuangan rumah sakit.

\section{Kerangka Pemikiran Teoritik}

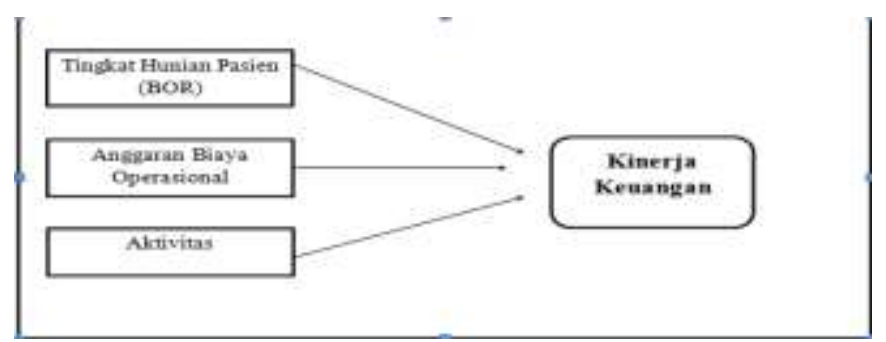

\section{Gambar II. 1 Kerangka Pemikiran \\ Teoretik}

\section{Perumusan Hipotesis Penelitian}

Berdasarkan logika dari paparan di atas maka dikembangkan suatu hipotesis atas penelitian ini, yaitu: H1:TingkatHunianPasien(BOR)berpen garuh terhadap Kinerja Keuangan. 
H2: Anggaran Biaya Operasional berpengaruh terhadap Kinerja Keuangan

H3 :Rasio Aktivitas berpengaruh terhadap Kinerja Keuangan

\section{METODOLOGI PENELITIAN}

\section{A. Tujuan Penelitian}

Berdasarkan masalah-masalah yang telah peneliti rumuskan, maka tujuan penelitian ini adalah untuk mengetahui secara empiris pengaruh efektivitas pelayanan, efektivitas penganggaran, dan pengelolaan aktivitas terhadap kinerja keuangan badan layanan umum rumah sakit di provinsi DKI Jakarta.

\section{B. Objek dan Ruang Lingkup Penelitian}

Objek penelitian ini adalah Seluruh Badan Layanan Umum di Indonesia dengan kriteria hanya sektor kesehatan Rumah Sakit Di Provinsi DKI Jakarta selama 5 tahun periode 2011-2015. Peneliti membatasi ruang lingkup penelitian ini pada pengaruh efektifitas pelayanan, efektifitas penganggaran dan aktivitas terhadap kinerja keuangan badan layanan umum rumah sakit di provinsi DKI Jakarta.

\section{Metode Penelitian}

Metode yang digunakan dalam penelitian ini menggunakan metode Deskriptif kuantitatif yang menggunakan cara-cara tertentu dalam mengumpulkan, mengolah, dan menganalisis data yang disajikan dan diukur dalam suatu skala numerik atau dalam bentuk angka-angka dengan teknik statistik, kemudian mengambil kesimpulan secara generalisasi untuk membuktikan adanya pengaruh dalam penelitian ini.

Penelitian ini menggunakan data sekunder (yang dianalisis menggunakan program SPSS/Eviews) berisi informasi laporan keuangan dan non keuangan yang diperoleh dari Kementriaan Keuangan Direktorat Pengelolaan Keuangan Badan Layanan Umum.

\section{Jenis dan Sumber Data}

Penelitian ini menggunakan data sekunder, yaitu data yang diperoleh secara tidak langsung dari perusahaan yang bersangkutan tetapi berasal dari lembaga pengumpulan data.

Data sekunder yang digunakan adalah data laporan keuangan, laporan kinerja serta laporan realisasi anggaran untuk periode tahun 2011-2015. Adapun metode pemilihan sampel penelitian menggunakan purposive sampling.

Purposive sampling merupakan suatu metode pengambilan sampel non probabilita yang disesuaikan dengan kriteria tertentu. Beberapa kriteria yang harus dipenuhi dalam penentuan data penelitian ini sebagai berikut:

1. Laporan keuangan Rumah Sakit Pemerintah yang telah menjadi BLU di Provinsi DKI Jakarta periode tahun 2011-2015.

2. Telah menjadi BLU penuh lebih dari 5 tahun.

\section{F. Operasionalisasi Variabel \\ Penelitian}


1. Variabel Dependen (Terikat)

Variabel dependen disebut juga variabel terikat yang berarti variabel ini dipengaruhi variabel independen dan biasanya disimbolkan dengan (Y). Dalam penelitian ini Kinerja Keuangan yang menjadi variabel dependen.

a. DefinisiKonseptual

Dalam penelitian ini variabel dependennya adalah kinerja keuangan berdasarkan kemampuan pendapatan PNBP menutupi biaya opersional (POBO). Analisis Kinerja keuangan ini dapat dilakukan baik oleh pihak eksternal maupun pihak internal satuaan kerja. Analisa POBO adalah jenis analisa keuangan yang membandingkan antara Pendapatan operasional dengan Biaya Operasional PNBP (POBO=Pendapatan Operasional Biaya Operasional). Analisa ini dulu sering disebut juga CRR atau Cost Recovery rate. Sehingga peniliaian analisis POBO yang baik bisa di lihat dari beberapa sisi. Bahwa kinerja keuanganatas pendapatan operasional BLU yang baik hingga dapat menutupi biaya opersional yang terjadi merupakan indikasi naiknya pendapatan operasional yang dicapai suatu instansi dibidang keuangan sehingga mencerminkan tingkat kesehatan perusahaanpada bidang tersebut.

Analisis POBO ini jugaberguna untuk melihat efisiensi biaya sekaligus kreatifiitas pimpinan BLU dalam meningkatkan pendapatan. Kedua hal ini naik pendapatan maupun biaya saling terkait dan saling berkontribusi dalam hasil perhitungan POBO.

b. Definisi Operasional

Sistem penilaian kinerja keuangan Rumah Sakit BLU memilikibeberapa indikator yang merupakan alat yang dapat digunakan untuk menilai suatu proses kegiatan BLU Rumah Sakit secara terus menerus. Sebagai rumah sakit milik Negara, BLU rumah sakit harus mampu memberikan informasi yang menggambarkan kemajuan rumah sakit pada suatu periode tertentu.

Kementerian kesehatan dan Kementerian keuangan sebagai dua kementerian yang membawahi Rumah sakit BLU menganggap analisa POBO ini sangat penting dan pantas karena hanya satusatunya indikator keuangan yang dipakai dalam penilaian Kinerja pimpinan Rumah Sakit Badan Layanan umum (BLU).

Indikator yang dinilai untuk BLU rumah sakit sesuai Kementerian Keuangan Republik Indonesia Peraturan Direktur Jendral Perbendaharaan Nomor PER/34/PB/2014 memiliki rumus : $=\quad$ Pendapatan Operasional (PNBP)

Biaya Operasional

Pendapatan PNBP merupakan pendapatan yang diperoleh sebagai imbalan atas barang/jasa yang diserahkan kepada masyarakat yang terdiri dari pendapatan usaha dari jasa layanan ditambah hibah ditambah pendapatan lain-lain diluar usaha dan tidak termasuk 
pendapatan yang berasal dari APBN.

Biaya operasional merupakan seluruh biaya yang dibutuhkan dalam memberikan pelayanan kepada masyarakat, yang terdiri dari belanja pegawai dan belanja barang, dan sumber dananya berasal dari penerimaan anggaran APBN dan pendapatan PNBP Satker BLU.

\section{Variabel Independen (Bebas)}

Variabel independen disebut jugavariabel bebas dimana variabel ini dapat mempengaruhi variabel secara bebas atau mempengaruhi secara positif maupun negatif dan biasanya disimbolkan dengan(X).

Adapun variabel independenyang digunakan dalam penelitian iniyaitu:

a. Tingkat Hunian Pasien (BOR)

1) DefinisiKonseptual

- Salah satu Indikator penilaian efesiensi pelayanan Rumah Sakit yaitu penyedian fasilitas kesehatan dalam variable ini adalah tingkat hunian Bed Occupancy Rate (BOR) yang baik turut menunjang kinerja pelyanan rumah sakit. Hal ini untuk memenuhi kebutuhan dan keinginan pasien sehingga dapat memperoleh kepuasan yang ada pada akhirnya dapat meningkatkan kepercayaan pada rumah sakit melalui pelayanan prima. Melalui pelayanan prima, rumah sakit diharapkan akan menghasilkan keunggulan kompetitif dengan pelayanan bermutu, efisien, dan inovatif sehingga pendapatan akan bertambah dan kinerja keuangan akan meningkat.
2) DefinisiOperasional

Bed Occupancy Rate (BOR) Menurut Departemen Kesehatan RI, BOR adalah prosentase pemakaian tempat tidur pada periode tertentu. Indikator ini memberikangambaran tinggi rendahnya tingkat pemanfaatan tempat tidur di rumah sakit. Nilai parameter BOR yang ideal adalah antara 60-85\% (Depkes RI, 2005). Adapun rumus BOR adalah:

$\mathrm{BOR}=$ Jumlah hari perawatan rumah sakit $\mathrm{X}$ $100 \%$

(Jumlah tempat tidur $\mathrm{x}$ jumlah hari dalam satu periode)

\section{b. Anggaran Biaya Operasional}

1) DefinisiKonseptual

Anggaran biaya operasional adalah anggaran atau taksiran semua biaya yang dikeluarkan dan pada hakekatnya dianggap habis dalam masa tahun buku. Pada Badan Layanan Umum Rumah Sakit yang merupakan salah satu satuan kerja dari pemerintah pusat yang mendapatkan dana anggaran dari APBN. Anggaran biaya operasional termasuk didalamnya seluruh biaya yang dibutuhkan dalam memberikan pelayanan kepada masyarakat, yang terdiri dari belanja pegawai dan belanja barang, dan sumber dananya berasal dari penerimaan anggaran APBN dan pendapatan PNBP Satker BLU.

\section{2) DefinisiOperasional}

Perhitungan rumus yang digunakan pada penelitian ini adalah sebagai berikut: 


\section{$=\quad$ Realisasi Anggaran Biaya \\ Operasional \\ Target Anggaran Biaya \\ Operasional \\ (Sumber diolah penulis,2016)}

Perhitungan rumus tersebut

berdasarkan laporan realisasi

anggaran berdasarkan Sistem

Akuntansi Pemerintah yang tidak memasukan biaya modal dalam komponen Anggaran Biaya Operasional BLU RS, sesuai dengan penjabaran definisi dari belanja modal di pembahasan sebelumnya

c. Aktivitas

1) Definisi Konseptual

Rasio aktivitas dapat menggambarkan kinerja keuangan rumah sakit dalam pengelolaan persediaan dan piutangnya serta mengukur seberapa efektif (hasilguna) perusahaan menggunakan sumber dayanya secara optimal dengan cara membandingkan rasio aktivitas dengan standar industri dapat diketahui tingkat efisiensi perusahaan dalam industri

2) Definisi Operasional

Rasio Aktivitas menggunakan pengukuran yang melihat pada beberapa aset kemudian menentukan beberapa tingkat aktivitas aktiva -aktiva tersebut pada tingkat kegiatan tertentu. Aktivitas yang rendah pada tingkat penjualan tertentu akan mengakibatkan semakin besarnya dana kelebihan yang tertanam pada aktiva - aktiva tersebut.
Perhitungan rumus yang digunakan pada penelitian ini adalah sebagai berikut:

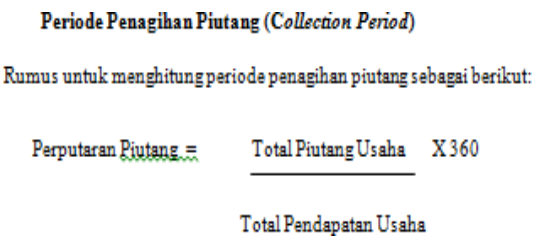

\section{G. Teknik Analisis Data}

1. Analisis Statistik Deskriptif

Statistik deskriptif merupakan gambaran atau deskripsi suatu data yang dilihat dari nilai rata-rata (mean), median, modus, standar deviasi, maksimum, dan minimum yang kemudian menjadi sebuah informasi yang jelas dan dapat dipahami.

2. Uji Asumsi Klasik

Uji asumsi klasik bertujuan untuk mengetahui apakah model regresi benar-benar menunjukkan hubungan yang signifikan dan mewakili (representatif) maka model tersebut harus memenuhi uji asumsi klasik regresi yang meliputi:

a. Uji Normalitas Data

Uji normalitas menurut Ghozali (2013:165) bertujuan untuk menguji apakahdalam model regresi,variable pengganggu atau residualmempunyai distribusi normal. Seperti diketahui bahwa uji $t$ dan $F$ mengasumsikan nilai residual mengikuti distribusi normal. Jika asumsi ini tidak terpenuhi maka hasil uji statistic menjadi tidak valid khusunya untuk ukuran sampel kecil. Dalam penelitian ini digunakan dua cara untuk melakukan uji normalitas data yaitu analisis grafik dan analisis statistik.

1) Analisis grafik

Alat uji yang digunakan adalah menggunakan analisis grafik norma 
plot. Adapun dasar pengambilan keputusannya adalah :

a) Jika titik menyebar di sekitar garis diagonal atau mengikuti arah garis diagonal maka model regresi memenuhi asumsi normalitas.

b) Jika titik menyebar jauh dari garis diagonal atau tidak mengikuti arah garis diagonal maka model regresi tidak memenuhi asumsi normalitas (Ghozali, 2011).

2) Analisis statistik

Selain menggunakan grafik, penelitian ini juga menggunakan uji statistik denganKolmogorovSmirnov Z (1-Sample K-S). Dasar pengambilan keputusan pada analisis Kolmogorov-Smirnov $\mathrm{Z}$ adalah sebagai berikut:

a) Apabila nilai Asymp. Sig. (2-tailed) kurang dari 0,05 maka Ho ditolak. Hal ini berarti data residual terdistribusi tidak normal.

b) Apablia nilai Asymp. Sig. (2tailed) lebih besar dari 0,05 maka Ho diterima. Hal ini berarti data residual terdistribusi dengan normal (Ghozali, 2011).

b. Uji Multikolinieritas

Uji multikolenieritas bertujuan untuk menguji adanya hubungan linier diantara variabel-variabel bebas dalam persamaan regresi. Bila variabel-variabel bebas berkolerasi secara sempurna, maka persamaan regresi yang dihasilkan tidak dapat digunakan.Dengan demikian regresi linier klasik mengasumsikan tidak terjadinya multikolinieritas diantara variabelvariabel bebas.Untuk mendeteksi adanya multikolenieritas dapat dilakukan dengan uji Variance
Inflation Faktor (VIF) dan matrik korelasi antar variabel bebas yang dihitung dengan menggunakan SPSS 21. Model dikatakan tidak terjadi multikolinieritas apablia (Suliyanto, 2005:75) :

1) Output SPSS 21 pada

coefficients menunjukkan nilai VIF

$<10$ atau nilai tolerance $>0,10$

2) Output SPSS 21 pada coefficients correlations menunjukkan nilai korelasi antar variabel bebasnya $<0,5$

c. Uji Autokorelasi

Menurut Ghozali (2013:137) Uji Autokorelasi ini bertujuan untuk menguji apakah dalam model regresi linear ada korelasi antara kesalahan pengganggu (residual) pada periode $t$ dengan kesalahan pada periode $\mathrm{t}-1$ (sebelumnya).

Jika terjadi korelasi, maka dinamakan ada masalah autokorelasi. Autokorelasi muncul karena observasi yang berurutan sepanjang waktu berkaitan satu sama lain. Masalah ini timbul karena residual (kesalahan pengganggu) tidak bebas dari satu obeservasi ke observasi lainnya. Hal ini sering ditemukan pada data runtun waktu atau time series karena "gangguan" pada seseorang individu atau kelompok cenderung mempengaruhi "gangguan" pada individu atau kelompok yang sama pada periode berikutnya. Pada data cross-section (silang waktu), masalah autokorelasi relative jarang terjadi karena "gangguan" pada observasi yang berbeda berasal dari individu atau kelompok yang berbeda. Model regresi yang baik adalah regresi yang bebas dari autokorelasi. Salah satu cara untuk mengetahui ada atau tidaknya korelasi yaitu dengan melakukan uji Run Test.

d. Uji Heterokedastisitas 
Uji heterokedastisitas digunakan untuk mengetahui apakah terjadi penyimpangan model karena gangguan varian yang berbeda antar observasi satu ke observasi lain. Heteroskedastisitas tidak menyebabkan estimator (koefisien variabel independen) menjadi bias karena residual bukan komponen menghitungnya. Namun, menyebabkan estimator jadi tidak efisien dan BLUE lagi serta standard error dari model regresi menjadi bias sehingga menyebabkan nilai $\mathrm{t}$ statistik dan F hitung bias (misleading). Dampak akhirnya adalah pengambilan kesimpulan statistik untuk pengujian hipotesis menjadi tidak valid.

Ada dua cara untuk mendeteksi ada tidaknya heteroskedastisitas, yaitu metode grafik dan metode uji statistik (uji formal). Metode grafik relatif lebih mudah dilakukan namun memiliki kelemahan yang cukup signifikan karena jumlah pengamatan mempengaruhi tampilannya.

Semakin sedikit jumlah pengamatan semakin sulit menginterpretasikan hasil grafik plots. Selain itu, interpretasi setiap orang dengan melihat pola grafik bisa berbeda-beda.Oleh sebab itu diperlukan uji statistik formal yang lebih dapat menjamin keakuratan hasil.

3. Uji Hipotesis

a. Analisis Regresi

Dalam Somantri (2011:243), dinyatakan bahwa Regresi linier sederhana bertujuan untuk mempelajari hubungan linier antar dua variabel. Sedangkan dalam Sugiyono (2011:261), dinyatakan bahwa Regresi sederhana didasarkan pada hubungan fungsional ataupun kausal satu variabel independen dengan satu variabel dependen. Model regresi linier sederhana : $\hat{\mathrm{y}}=\mathrm{a}+\mathrm{bx}$, dimana ŷ adalah variabel tak bebas (nilai duga), $\mathrm{x}$ adalah variabel bebas, a adalah penduga bagi intersap $(\alpha)$, b adalahpenduga bagi koefisien regresi ( ), dan $\alpha, \beta$ adalah parameter yang nilainyatidak diketahui sehingga diduga menggunakan statistik sampel.

Analisis regresi dalam penelitian ini adalah analisis regresi berganda yang digunakan untuk mengetahui pengaruh Efektifitas Pelayanan, Efektifitas Penanggaran, dan Aktivitas terhadap Kinerja Keuangan Badan Layanan Umum Adapun bentuk model yang akan diuji dalam penelitian ini yaitu:

$Y=\alpha+\beta_{1} X_{1}+\beta_{2} X_{2}+\beta_{3} X_{3}+e$

Keterangan :

$\mathrm{Y}=$ Kinerja Keuangan

$\alpha=$ Konstanta

$\beta_{1}-\beta_{3}=$ Koefisien Regresi

$\mathrm{X} 1=$ Efektifitas Pelayanan

$\mathrm{X} 2$ = Efektifitas Pengaanggaran

$\mathrm{X} 3=$ Aktivitas

$\mathrm{e}=$ error

b. Uji Signifikan Parsial (Uji t)

Menurut Ghozali (2011:98) uji statistik $t$ pada dasarnya menunjukkan seberapa jauh pengaruh satu variable penjelas/independen secara individual dalam menerangkan variasi variabel dependen.

Hipotesis yang akan diuji :

Ho : $\beta=0$, artinya variabel independen tidak berpengaruh signifikan terhadap Kinerja Keuangan

H1 : $\beta \neq 0$, artinya variabel independen berpengaruh signifikan terhadapKinerja keuangan Dengan ketentuan sebagai berikut : 1) Jika t-hitung < t-tabel dan probitabilitas >0,05 makan Ho diterima dan $\mathrm{H} 1$ ditolak untuk $\alpha=$ $5 \%$. 
2) Jika t-hitung > t-tabel dan probitabilitas > 0,05 makan Ho ditolak dan $\mathrm{H} 1$ diterima untuk $\alpha=$ $5 \%$.

c. Uji Signifikan Simultan (Uji F)

Menurut Imam Ghozali Uji statistik

F pada dasarnya menunjukkan apakah semua variabel bebas yang dimasukkan dalam model mempunyai pengaruh secara bersama-sama terhadap variabel terikat.

Untuk menguji kedua hipotesis ini digunakan uji statistik $\mathrm{F}$ :

1) Taraf signifikan $\alpha=0,05$

2) Kriteria pengujian dimana $\mathrm{Ha}$ diterima apablia $\mathrm{p}$ value $<\alpha$ dan $\mathrm{Ha}$ ditolak apablia $\mathrm{p}$ value $>\alpha$.

d. Koefisien Determinasi (R2)

Koefisien determinasi (R2) pada intinya mengukur seberapa jauh kemampuan model dalam menerangkan variasi variable dependen (Ghozali, 2011:97).Nilai koefisien determinasi adalah antara nol dan satu. Jika koefisien determinasi semakin mendekati 1 maka semakin kuat pengaruh variableindependen terhadap variabel dependen dan koefisien determinasi mendekati 0 , maka dapat dikatakan semakin kecil pengaruh variabel independen terhadap variabel dependen

\section{HASIL PENELITIAN DAN PEMBAHASAN \\ A. Deskripsi Data}

Data dalam penelitian ini menggunakan data sekunder yang didapat dari laporan keuangan, laporan realisasi anggaran dan laporan kinerjaBLU RS yang terdapat kolektif di Kementerian Keuangan PK-BLU dan Direktorat Yankes Kemenkes RI.

Berdasarkan data BLU yang terdaftar di PK-BLU sampai dengan Desember 2016 berjumlah 182 unit satuan kerja. Dari data tersebut dikurangi dengan BLU selain sektor kesehatan yang terdaftar di PK-BLU sejumlah 110 satker, lalu dikurangi BLU Sektor Kesehatan yang bukan RS sejumlah 7 satker, dikurangi BLU RS yang bukan di DKI Jakarta sejumlah 53 satker, danBLU RS yang terbentuk di 2015-2016sejumlah 3 satker. Sehingga diperoleh jumlah BLU yang dapat dijadikan sample penelitian sejumlah 9 BLU RS dengan jumlah data penelitian 45 data.

\section{B. Pengujian Hipotesis}

\section{HasilUji StatistikDeskriptif}

Hasil pengujian statistik deskriptif pada tabel IV.3 menampilkan karakteristik sampel yang digunakan untuk penelitian ini yang meliputi jumlah sampel(n), rataratasampel (mean), nilai maksimum, nilai minimum dan standar deviasi untukmasingmasing variabel.Berikutdata dilakukan uji descriptive statistics, hasil dari pengujian statistik deskriptif dari variabel POBO, Anggaran Biaya Operasional, dan Aktivitasdari tahun 2011- 
2015disajikan dalam tabel dibawah ini.

2. Hasil Uji Asumsi Klasik

a. Uji Normalitas

Pengujian ini dimaksudkan untuk mengetahui apakah dalam model regresi, variabel mempunyai distribusi normal. Penulis menggunakan program SPSS (StatisticProductionSolutionService ) versi 21.0 for Windows untuk mengolah data penelitian. Dalampenulisanskripsiinianalisadat adilakukanberdasarkan periode data yang diteliti dengan tujuan agar diperoleh informasi pengaruh variabelindependenterhadapvariabe ldependen kinerja keuangan pada BLU RSpada periodetersebut,yaituanalisaberdasa rkanpooleddatatahun2011sampaide ngan2015.

\section{KESIMPULAN, IMPLIKASI, DAN SARAN}

\section{A. Kesimpulan}

Data dalam penelitian ini menggunakan data sekunder yang didapat dari laporan keuangan, laporan realisasi anggaran dan laporan kinerjaBLU RS yang terdapat

Berdasarkanhasilanalisisdatadanpemb ahasanyangtelahdilakukandi bab sebelumnyamakadapat ditarik kesimpulan sebagai berikut:

1. Hipotesis 1 diterima yang menunjukkan bahwa tingkat hunian Jurnal IImiah Wahana Akuntansi pasien / Bed Occupancy Rate(BOR) berpengaruh secara signifikan terhadap kinerja keuangan berdasarkan kemampuan pendapatan PNBP menutupi biaya operasional pada BLU RS yang terdaftar di PK BLU Kementerian Keuangan tahun 2011-2015.

2. Hipotesis 2 diterima yang menunjukkan bahwa anggaran biaya opearasional berpengaruh signifikan terhadap kinerja keuangan berdasarkan kemampuan pendaapatan menutupi biaya operasional pada BLU RS yang terdaftar di PK BLU Kementerian Keuangan tahun 20112015.

3. Hipotesis 3 ditolak yang menunjukkan bahwa rasio aktivitas tidak berpengaruh secara signifikan terhadap kinerja keuangan berdasarkan kemampuan pendaapatan menutupi biaya operasional pada BLU RS yang terdaftar di PK BLU Kementerian Keuangan tahun 20112015.

4. Analisa data yang dilakukan terhadap kinerja keuangan BLU RS DI DKI Jakarta melalui tingkat hunian pasien (BOR), penyerapan anggaran biaya operasional, dan aktivitas penagihan piuang rumah sakit menunjukkan peningkatan rata-rata tiap tahunnya pada.

\section{B. Implikasi}


Dari penelitian yang telah dilakukan terdapat implikasi penelitian yang timbul diantaranya :

1. Penelitian ini menunjukan bahwa ada hubungan yang signifikan antara tingkat hunian pasien (BOR) dengan kinerja keuangan (POBO) BLU RShal ini berimplikasi pada pemanfaatan fasilitas tempat tidur yang efisien akan mengakibatkan peningkatan pelayanan rumah sakit yang berdampak pada naiknya pendapatan pelayanan rumah sakit. BOR sangat penting dalam pengambilan keputusan perencanaan rumah sakit, oleh karena itu upaya peningkatan kunjungan rumah sakit harus terus di tingkatkan salah satunya dengan pemanfaatan layanan rawat inap agar pendapatan juga mengalami peningkatan.

2. Pengaruh hubungan yang signifkan antara anggaran biaya operasional dengan kinerja keuangan (POBO) BLU RS juga diteliti pada penelitian ini. Sehingga impliksi yang timbul dengan pemanfaatan anggaran biaya operasional secara efisien berimbas pada penyerapan anggaran yang optimal, sehingga kemampuan rumah sakit dalam pengendalian biaya operasionalpun akan meningkatkan kinerja keuangan.

3. Penelitian ini juga turut mendukung penelitan sejenis yang memiliki hasil pengaruh signifikan berdasarkan tingkat hunian terhadap kinerja keuangan dan anggaran biaya opersional dengan kinerja keuangan secara parsial.

\section{Saran}

Berdasarkan hasil penelitian maka saran yang dapat diberikan untuk penelitian berikutnya adalah:

1. Penelitian selanjutnya diharapkan menggunakan sample Badan Layanan Umum yang lebih luas, mencakup seluruh sektor kesehatan sehingga memungkinkan kebaruan hasil penelitian yang akan berguna bagi pertumbuhan ekonomi di Indonesia.

2. Diharapkan menggunakan sample perbandingan periode tahun penelitian sebelum dan sesudah menjadi BLU di Indonesia sehingga, Badan Layanan Umum dapat terukur kinerjanya dengan hasil penelitian terbaru.

3. Diharapkan untuk pengambilan data sekunder diikuti dengan data primer berupa wawancara terhadap pegawai di instansi terkait sehingga dapat dihasilkan penelitian yang lebih menyeluruh dan valid.

4. Diharapkan bagi penelitian selanjutnya dapat meneliti BLU yang ada di daerah-daerah atau disebut BLUD di berbagai sektor.

5. Diharapkan dapat meneliti dengan variable-variabel lain yang tidak diteliti dalam penelitian ini dan belum banyak diteliti tetapi relevan sehingga diperlukan untuk dilakukan penelitian,namun dapat menggunakan objek penelitian 
yang samadengan memperluas serta memperpanjang waktu penelitian agar dapat membandingkan apakah terdapat hasil yang berbeda.

6. Agar Penelitian selanjutnya bisa melakukan klasifikasi rumah sakit sebagai sample, dibandingkan menganalisis rumah sakit sebagai kelompok sample (sample penelitian).

\section{DAFTAR PUSTAKA}

Adam, IY. Hubungan Rasio Lancar dengan BOR antar Rumah Sakit. [skripsi]. Jakarta (ID): Universitas Indonesia. 2008.

Amallia Chairun. Analisis Kinerja Keuangan Rumah Sakit Jiwa Prof HB. Sanin sebelum dan sesudah ditetapkan menjadi Badan Layanan Umum. Jurnal Akuntansi FE Universitas Padang.

Brigham,F.EugenedanJoelF.Houston.Dasar -dasarManajemen.Terjemahan

Ali Akbar YuliantoJakarta: Salemba empat, 2010.

Candri, Carolina. Analisis Kinerja Keuangan Badan Layanan Umum dan Penentuan Status Subjek Pajaknya.Jakarta: Universitas Indonesia. 2007

Direktorat Jenderal Bina Pelayanan Medik, Kementerian Kesehatan RI. Pedoman Akuntansi BLU Rumah Sakit. 2012.

Direktorat Jenderal Pelayanan Medik Departemen Kesehatan Republik Indonesia. Indikator Kinerja Rumah Sakit. Jakarta (ID): Departemen Kesehatan RI. 2005.

Jurnal IImiah Wahana Akuntansi
Departemen Kesehatan Republik Indonesia. 2005. Buku Petunjuk Pengisian, Pengelolaan dan Penyajian Data Rumah Sakit. Jakarta: Penerbit Dikjen Bina Pelayanan Medik.

Direktorat PPK BLU. Arsip Konsultasi. http://www.ppkblu.depkeu.go.id/ index.php/baca/ berita/44/arsip-konsultasi. (diakses Desember 2016)

Dwi, Putri.Pengaruh Rasio Likuiditas, Rasio Leverage, dan Rasio AktivitasTerhadap Kinerja Keuangan.Jurnal Administrasi Bisnis. Vo. 8 No. 1, Februari 2014.

Fahdi Muhammad,Ria Nelly SaridanM. Rasuli. Faktor-Faktor yang pengaruhi Kinerja Satuan Kerja Badan LayananUmum Universitas Riau. Program Studi Masgister Akuntansi Fakultas Ekonomi Universitas Riau. 2013

Ghozali, Imam. Aplikasi Analisis Multivariate Dengan Program SPSS.

Semarang: Badan PenerbitUniversitas Diponegoro. 2011

Hanafi, M Dr. Mahmud. Manajemen

Keuangan. Yogyakarta: Dosen Fakultas

Ekonomi Universitas Gadjah Mada,2011.

John J. Wild \& K. R. Subramanyam. Analisi Laporan Keuangan. Jakarta : Salemba Empat. 2012.

Jumingan. 2011. Analisis Laporan Keuangan. Jakarta: Bumi Aksara

Karno, Shinta Sukma Devi. Analisis Anggaran Biaya Operasional dan 
Anggaran Pendapatan Terhadap Kinerja Keuangan Berdasarkan Rasio Return on Asset (ROA) Pada PT. Graha Sarana Duta Palembang. Jurusan Akuntansi, STIE MDP. 2012.

Kurniawan Chandra. Analisis Pengaruh Pemberlakuan Anggaran Berbasis Kinerja Keuangan PemerintahDaerah Kota MetroFakultas Ekonomi Universitas Lampung

Kasmir. 2013. Analisis Laporan Keuangan. Jakarta: PT Raja Garfindo

Kuswadi. Memahami Rasio-Rasio Keuangan Bagi Orang Awam. Jakarta: PT. Elex Media Komputindo. 2006.

Mahfiza. Pengaruh Sistem Pengelolaan Keuangan Terhadap Efektivitas Penganggaran Pada Badan Layanan Umum (Blu) Universitas Negeri GorontaloAlBuhutsISSN 1907-0977 E ISSN 2442823X Volume 11 Nomor 1 Juni 2015 Halaman 134-150

Mardiasmo..Akuntansi Sektor Publik . Penerbit Andi. Yogyakarta. 2006.

Mahsun, Mohamad.. Pengukuran Kinerja Sektor Publik. BPFE. Yogyakarta. 2009.

Mahmudi. Manajemen Kinerja Sektor Publik. UPP AMP YKPN Yogyakarta 2005.

Mahmudi. New Publict Management (NPM) : Pendekatan Baru Manajemen Sektor Publik, http://journal.vii.ac.id/index.php/sinerji/arti kel, 2003.
Meidyawati. (2011). Analisis Implementasi Pola Pengelolaan Keuangan Badan Layanan Umum (PPK-BLU) Pada Rumah Sakit Stroke Nasional Bukit Tinggi.

Nurul et al, Analisis Implementasi Pola Penngelolaan Badan Layanan Umum Pada Rumah Sakit Daerah Kalisat - Jember. Artikel Ilmiah Mahasiswa 2013.

Nurani Nani. Peranan Anggaran Biaya Operasional Sebagai Alat Pengendalian Manajemen Pada PT SariWangi AEA, Jurnal. 2009.

Nurdiansyah, Dian Hakip. Analisis Sistem Penganggaran Serta Pengaruhnya Terhadap Kinerja Keuangan Yayasan AsSyifa (Studi Kasus Pada Yayasan As-Syifa Al-Khoeriyah)

Nofitasari, Dwi. Analisis Kinerja UPT Rumah Sakit Paru Jember Sebelum dan Sesudah Badan Layanan Umum (BLU).Tidak Dipublikasikan. Skripsi. Jember: Universitas Jember. 2013.

Peraturan Pemerintah Nomor 23 Tahun 2005 tentang Pengelolaan Keuangan Badan Layanan Umum (BLU), sebagaimana diubah dengan Peraturan Pemerintah Nomor 74 Tahun 2012.

Peraturan Menteri Keuangan Nomor 76/PMK.05/ 2008 tentang Pedoman Akuntansi Badan Layanan Umum

Peraturan Menteri Dalam Negeri Nomor 61 Tahun 2007 tentang Pedoman Teknis Pengelolaan Keuangan Badan Layanan 
Umum Daerah. Rumah Sakit Umum Daerah Dr. Haryoto Lumajang. 2014

Prakoso, Cathas Teguh. Eksistensi Badan Layanan Umum Ditinjau Dalam Perspektif New Institutional Dan Principal-Agent Theory.eJournal Administrative Reform, 2014

Pramono Joko. Analisis Rasio Keuangan Untuk Menilai Kinerja Keuangan Pemerintah Daerah (Studi Kasus Pemerintah Kota Surakarta)Among Makarti, Vol. 7 No. 13 , Juli 2014.

Riadi. R.M. Analisis Pengaruh Rasio Aktivitas Terhadap Rentabilitas Ekonomi Pada Perusahaan Plastics and Glass Products yang Go Publik di Bursa Efek Jakarta Selama Tahun 2002-2005Staff Pengajar pada FKIP-Jurusan P-IPS Program Studi Pendidikan Ekonomi. 2007

Rodrigues, Ana Paula. The impact of internal and external market orientation on performance in local public organisations Marketing Intelligence \& Planning Vol. 30 No. 3, 2012 pp. 284-306

Sari Dian. Pengaruh Partisipasi Anggaran dan Akuntansi Pertanggungjawaban Terhadap Kinerja Manajerial PT Pos Indonesia, e - Jurnal Binar Akuntansi, Vol.2 No.1. 2013

Singgih Santoso. Panduan Lengkap SPSS Versi 20 Edisi Revisi. Jakarta: PT. Elex Media Komputindo. 2014.

Sophia, Poppi Analisis implementasi pengelolaan keuangan Badan Layanan Umum (BLU) di Rumah Sakit Dr. Hasan
Sadikin (RSHS), Bandung-Jawa Barat Tahun 2006

Supriyanto dan Suparjo, "Badan Layanan Umum: Sebuah Pola Baru Pemikiran Atas Unit Pelayanan Masyarakat”. www.perbendaharaan.go.id

Surya Sherly Kartika. Analisis Kinerja Keuangan dan Non Keuangan Rumah Sakit Umum Daerah Dr. Haryoto Lumajang Sebelum dan Sesudah Implementasi Badan Layan UmumArtikel Ilmiah Mahasiswa. 2015

Sumarto, Analisis BOR dalam penilaian Kinerja Keuangan pada RS Atma Jaya. [thesis]. Jakarta (ID): Universitas Katolik Indonesia Atma Jaya. 2002.

Sumenge Ariel S. Analisis Efektifitas dan Efesiensi Pelaksanaan Anggaran Belanja Badan Perencanaan Pembangunan Daerah (BAPPEDA) Minahasa Selatan Jurnal EMBA. Vol. 1 No. 3September, 2013. Hal 74-81

Undang-Undang Nomor 1 Tahun 2004 tentang Perbendaharaan Negara

Undang-Undang Republik Indonesia Nomor 1 Tahun 2004 tentang Perbendaharaan Negara.

Undang-Undang Republik Indonesia Nomor 17 Tahun 2003 tentang Keuangan Negara.

Waluyo, Indarto. 2011. Badan Layanan Umum Sebuah Pola Baru Dalam Pengelolaan Keuangan Di Satuan Kerja Pemerintah. JurnalPendidikan Akuntansi Indonesia, Vol. IX (2): 1-15. 
Waluyo.Budi Analisis Permasalahan pada implementasi pola pengelolaan badan layanan umum.Jurnal Infoartha Vol. 3/Tahun XII/2014 (27-38)

Yusri Chaeroniza. Analisis Pengaruh Kinerja Pelayanan Terhadap Kinerja Keuangan pada RS. Bogor Medical Center. Skripsi Sarjana Alih Jenis Manajemen, Fakultas Ekonomi dan Manjemen, Institusi Pertanian Bogor.

https://id.wikipedia.org/wiki/Badan_Layan an_Umum (Diakses tanggal 09 September 2016)

http://girimahendra.blogspot.com/2013/05/ pengujian-hipotesis-uji-koefisien.html (Diakses tanggal 09 September 2016)

http://www.jdih.kemenkeu.go.id/fulltext/2 005/23TAHUN2005PP.HTM (Diakses tanggal 12 September 2016) 